\title{
Evasão escolar e educação profissional
}

\section{Denise Bianca Maduro Silva}

DORE, Rosemary; ARAúJO, Adilson César de; MENDES, Josué de Sousa (Orgs.). Evasão na educação: estudos, políticas e propostas de enfrentamento. Brasília: Editora do IFB/RIMEPES, 2014, 466p. Disponível em: http://www.fae.ufmg.br/ rimepes/livros.html.

O livro é um dos primeiros lançados no País sobre o problema da evasão escolar, que explodiu com a ampliação do acesso à educação de nível médio, especialmente o ensino técnico. As pesquisas realizadas pela Rede Ibero-Americana de Estudos sobre Educação Profissional e Evasão Escolar (RIMEPES) foram pioneiras no estudo do abandono escolar na educação profissional.

Um dos resultados negativos do abandono escolar é a dificuldade dos indivíduos em se inserir no mundo do trabalho, sem uma qualificação profissional, o que traz consequências indesejáveis para ele e para o crescimento econômico dos países, contribuindo para o aumento da desigualdade social. Em Crescimento econômico e educação: o papel das desigualdades sociais, o economista Fiorentini situa esse problema no contexto internacional.

As desigualdades educacionais relacionam-se não só à estrutura econômica, mas às políticas públicas adotadas nas últimas décadas. As reformas neoliberais obedecem a critérios econômicos homogêneos, centrados mais nos meios do que nos fins, desconsiderando a participação da sociedade, a diversidade dos povos e as crescentes desigualdades. Esse é o foco do artigo de Martínez, em Educación y trabajo juvenil: los desafíos de la educación media técnico profesional en Chile, Agüero, por sua vez, também aborda as reformas neoliberais em La política de educación técnica para el trabajo en el Perú entre los años 1990 y 2013. Para o autor, a partir dos anos 1990, o governo promoveu a abertura dos mercados, a mercantilização da educação e a regulação e padronização da qualidade educativa. Contudo, as propaladas melhorias para a educação técnica no país não foram alcançadas.

As políticas neoliberais para a educação reforçam a dualidade entre formação técnicoprofissional, destinada a funções subalternas na atividade produtiva, e a formação 
acadêmica voltada a preparar quadros dirigentes. A democratização crescente do acesso à escolarização de nível médio, em âmbito mundial, não contrariou essa tendência, mas a fortaleceu e aprofundou. Esse problema é abordado por Antunes e Sá em Quatro décadas de Portugal democrático. O que oferece aos jovens a educação profissional de nível secundário?. Os autores sintetizam quarenta anos de políticas educativas em Portugal, argumentando que o ensino médio técnico se insere na estrutura dual de organização da escola, que reproduz social e culturalmente as desigualdades sociais. Questões estruturais dos sistemas de ensino também são tratadas em Políticas, intinerarios y formación docente en la formación profesional española. Parejo relaciona a crise do ensino técnico ao caráter contraditório do nível médio: sua função compreensiva, pois como estágio final da educação obrigatória representa o capital cultural mínimo e as competências básicas a serem oferecidas a todos para exercício da cidadania, e sua função seletiva, por realizar a preparação para a escolaridade pós-obrigatória, a economia competitiva e a sociedade estratificada e legitimada pela meritocracia.

Desigualdade social e exclusão educacional caminham juntas e constituem o termômetro dos desafios da sociedade capitalista, principalmente em relação aos jovens e à sua formação escolar, problema que atinge diferentes países, sendo ressaltado, no caso da Itália, por Salatin, em Educação técnica de nível médio na Itália: quais políticas? Destinadas a quais jovens?

Os complexos vínculos entre escola e trabalho são tratados em três artigos. Um deles é de Miranda e Corica, El vínculo entre la educación secundaria y el mundo del trabajo: tensiones entre su complementariedad y su mutua exclusión. As autoras examinam os processos de inserção de estudantes do último ano do ensino médio no mercado de trabalho na Argentina. Outro estudo, realizado em Portugal, é o de Almeida, Gros, Machado e Queiroz, Itinerários de transição escola trabalho de jovens formados em centros de formação profissional: desenho do projeto de investigação. É sobre a trajetória de alunos de cursos de qualificação inicial de centros de formação profissional na transição ao mundo do trabalho, discutindo metodologias para analisar esse complexo percurso. No Brasil, a transição da escola técnica ao trabalho é objeto do artigo Transição escola - trabalho e perfis de estudantes evadidos e diplomados na educação profissional técnica no Brasil, elaborado por Paixão, Dore, Margiotta e Laudares. Os autores desenham os perfis sociodemográfico, econômico, educacional e ocupacional de 1.504 indivíduos que estão no mercado de trabalho, considerando os que obtiveram o diploma do ensino médio técnico e os que evadiram. Mostram que os diplomados apresentam perfil ocupacional significativamente melhor do que o dos evadidos, que ficam estagnados. Os dados aí analisados resultam de uma ampla pesquisa, coordenada pela professora Rosemary Dore (UFMG), sobre evasão e permanência no ensino médio técnico da Rede Federal de Educação Profissional e 
Tecnológica de Minas Gerais (RFEPT/MG), entre os anos de 2006 e 2010. Baseandose nas informações dessa pesquisa, foi escrito Evasão nos cursos técnicos de nível médio da rede federal de educação profissional de Minas Gerais, por Dore, Sales e Castro. Além de contemplar ampla revisão bibliográfica sobre evasão escolar e descrever o universo da investigação, as autoras discutem os fatores mais significativos associados ao problema do abandono escolar no ensino técnico. Mencionam, entre outros fatores, a dificuldade de compatibilizar estudos e trabalho, falta de identificação com o curso técnico e preferência por curso superior.

Outro texto sobre o abandono escolar no Brasil, em escolas públicas de nível médio estaduais no Município de São Leopoldo, Rio Grande do Sul, é o de Fritsch, Vitelli e Rocha, Para que jovens? Que políticas? - perfil de alunos ingressantes no ensino médio e políticas educacionais. A investigação realizada, entre 2011 e 2013, mostra um elevado nível de evasão associado, entre outros fatores, à defasagem idade-série e às dificuldades para conciliar estudo e trabalho.

No artigo Política de formación docente para educación profesional de nivel medio. La experiencia de México, Fuentes e Huitrón afirmam que a evasão escolar é um processo para o qual confluem diversos fatores que não podem ser hierarquizados. Para o abandono, concorre a falta de formação e atualização dos docentes do ensino médio, de ferramentas, metodologias e preparação para acompanhar, motivar e reter os estudantes.

Considerando a má formação inicial dos professores na Colômbia como um dos fatores relacionados à evasão escolar, Macia assina o artigo Formación inicial docente: sobre como se reproduce la baja calidad educativa. O texto apresenta os resultados ruins dos estudantes nos exames finais das licenciaturas, evidenciando a baixa qualidade na construção de competências pedagógicas durante os cursos.

Existe unanimidade nas pesquisas sobre como lidar com o fenômeno da evasão escolar: prevenir, adotar procedimentos para identificar os alunos que estão em situação de risco de abandonar a escola e envidar todos os esforços possíveis para impedir que isso ocorra. Depois que o aluno sai da escola, o seu retorno é muito mais difícil. A prevenção do abandono escolar depende muito dos recursos mobilizados pelas instituições e professores.

A experiência dos Estados Unidos no combate à evasão escolar é sintetizada nas estratégias apresentadas por La Plante. Em A epidemia da evasão escolar nos Estados Unidos: estratégias com impacto sobre a melhoria dos índices de formação e de oportunidades para manter viva a luta para acabar com a epidemia da evasão escolar, o autor discute um conjunto de iniciativas, não apenas governamentais, mas também 
da sociedade civil, voltadas a identificar e fomentar melhores práticas educativas para evitar o abandono escolar.

No Uruguai, uma estratégia para administrar o problema do abandono escolar é a Formação Profissional Básica (FPB), abordada por Lasida e Yapor, em El problema de la exclusión de la educación media uruguaya y una respuesta prometedora: la formación profesional básica. Trata-se de um curso de nível médio estruturado em torno de resultados de aprendizagens e práticas educativas que os autores consideram importante opção para os jovens evadidos retornarem aos estudos, embora apenas $40 \%$ dos estudantes o conclua.

Na Argentina, o Instituto Nacional de Educação Tecnológica (INET) do Ministério da Educação é um órgão criado para atuar na educação profissional. Suas políticas e seus programas para combater a evasão são focalizados por Otero, em Educación técnico profesional, política y gestión de la modalidad para el caso argentino.

A educação profissional e o fenômeno da evasão escolar constituem temas de primordial importância, especialmente com a forte tendência em expandir o acesso à escolaridade de nível médio, mormente no ensino técnico. Tal tendência, contudo, tem suscitado o problema da permanência dos estudantes até a conclusão de sua formação. $\mathrm{Na}$ obra resenhada, os autores abordam dimensões diferentes sobre o tema. Mostram como as desigualdades econômicas e sociais se traduzem em desigualdades escolares, como a universalização do ensino médio, particularmente no ensino técnico, tem sido orientada por políticas tendentes a manter as desigualdades sociais, a dualidade da escola. Destacam a necessidade de garantir a permanência dos indivíduos na escola como estratégia ímpar para lidar com o abandono escolar. Resultando de um difícil trabalho para reunir reflexões sobre uma temática que tem despertado o interesse e a preocupação de estudantes, pais, professores, pesquisadores e governantes, a leitura da obra é recomendada pela sua abrangência e seu aprofundamento.

Denise Bianca Maduro Silva é servidora da UFMG. Mestre em Ciências Sociais (FLACSO/Buenos Aires). Doutoranda no PPGE/UFMG - Doutorado Latino Americano da Faculdade de Educação da UFMG. Realizou doutorado sanduíche no PPGE/UnB entre 2016 e 2017. Email: profdenisebianca@gmail.com 